\title{
Human albumin infusion strategy in liver cirrhosis: liberal or restrictive?
}

\author{
Zhaohui Bai ${ }^{1,2}$, Gang Cheng ${ }^{2}$, Nahum Méndez-Sánchez ${ }^{3}$, Xingshun Qi ${ }^{1,2}$ \\ ${ }^{1}$ Department of Gastroenterology, General Hospital of Northern Theater Command, Shenyang, China; ${ }^{2}$ Department of Life Sciences and \\ Biopharmaceutics, Shenyang Pharmaceutical University, Shenyang, China; ${ }^{3}$ Medica Sur Clinic, National Autonomous University of Mexico, Mexico \\ City, Mexico \\ Correspondence to: Xingshun Qi. Department of Gastroenterology, Department of Life Sciences and Biopharmaceutics, General Hospital of Northern \\ Theater Command, Shenyang Pharmaceutical University, Shenyang, China. Email: xingshunqi@126.com.
}

Submitted Apr 25, 2021. Accepted for publication Jun 11, 2021.

doi: $10.21037 / \mathrm{atm}-21-2136$

View this article at: https://dx.doi.org/10.21037/atm-21-2136

Human albumin, which not only expands intravascular volume and improves microcirculation, but also binds numerous substances, such as bile acids, nitric oxide, and cytokines, has been widely employed for the management of several complications of cirrhosis in clinical practice $(1,2)$. However, the proper time duration and dosage and effect of human albumin in liver cirrhosis and its complications remain controversial (3-5).

Recently, a randomized control trial (RCT) has explored the effect of human albumin on patients with decompensated cirrhosis (6). It found that human albumin infusion was not more beneficial than standard care, and led to more severe or life-threatening serious adverse events, especially pulmonary edema and fluid overload. One of the major reasons for this unexpected phenomenon might be the use of a liberal human albumin infusion strategy that human albumin infusion would be continued, if serum albumin concentration was less than $35 \mathrm{~g} / \mathrm{L}$ in the albumin group (6). By comparison, a restrictive human albumin infusion strategy is often employed in previous studies and our clinical practice, because only a very low serum albumin concentration would significantly increase mortality. For example, serum albumin concentration $\leq 20 \mathrm{~g} / \mathrm{L}$ was significantly associated with a higher risk of spontaneous bacterial peritonitis recurrence in liver cirrhosis (7), and human albumin infusion improved the survival of spontaneous bacterial peritonitis (8). Additionally, serum albumin concentration $\leq 22.8 \mathrm{~g} / \mathrm{L}$ was an independent risk factor for death in liver cirrhosis with hepatic encephalopathy, and human albumin infusion decreased the in-hospital mortality of patients with hepatic encephalopathy $(9,10)$.

Another reason for this unexpected phenomenon is that the daily dosage and frequency of human albumin infused might be higher in the recent RCT (6). In the human albumin infusion group, the median total dosage of human albumin infused was $200 \mathrm{~g}$ per patient during two weeks, and the dosage of human albumin infused was $60-80 \mathrm{~g}$ per day in patients with serum albumin concentration $<25 \mathrm{~g} / \mathrm{L}$ at baseline (6). Such a liberal human albumin infusion strategy will lead to a rapid correction of serum albumin concentration, thereby causing more adverse events, which is consistent with the harms caused by a rapid correction of serum sodium concentration in patients with hyponatremia (11). By comparison, previous studies supporting the benefit of human albumin infusion employed a lower dosage of human albumin. For example, in a previous multicenter RCT, which showed a benefit of human albumin for prolonging the overall survival of cirrhosis with uncomplicated ascites and a similar incidence of non-liver related adverse events, the dosage of human albumin was $40-80 \mathrm{~g}$ per week for 18 months (12). In a cohort study, which showed a benefit of human albumin for improving the survival of cirrhosis with refractory ascites, but without any serious adverse event related to human albumin, the dosage of human albumin was $40 \mathrm{~g}$ per week for 24 months (13). In another RCT, which didn't show a benefit of human albumin infusion for preventing the development of complications and improving the survival of patients awaiting liver transplantation, but a similar incidence of treatment related adverse events, the 
dosage of human albumin was $40 \mathrm{~g}$ per 15 days (14). Our retrospective study, which showed the efficacy of human albumin infusion for preventing the development of hepatic encephalopathy and improving the outcomes of hepatic encephalopathy in cirrhosis, the median total dosage of human albumin was 30-40 g during hospitalizations (10). Regardless, central blood volume monitoring should be considered to prevent circulatory overload by optimizing the fluid balance, especially in cirrhotic patients receiving high dosage human albumin (1).

In addition, the study population who received human albumin infusion in the recent RCT was too heterogeneous (6). The current guideline recommended human albumin infusion for the prevention of post-paracentesis circulatory dysfunction after large volume paracentesis, spontaneous bacterial peritonitis, and hepatorenal syndrome in liver cirrhosis (1). However, $13.7 \%$ of the patients included in the human albumin group in the recent RCT had variceal bleeding (6). A high dosage of human albumin infused may increase the risk of volume overload in such patients, thereby probably elevating portal pressure (15).

Taken together, a restrictive human albumin infusion strategy might be more reasonable for cirrhotic patients, which should be in accordance with blood transfusion strategy in cirrhosis with acute gastrointestinal bleeding (16). Besides, considering that higher dosage and frequency of human albumin will lead to economic burden and waste of medical resources, the appropriate use of albumin in patients with cirrhosis should be crucial.

\section{Acknowledgments}

Funding: None.

\section{Footnote}

Provenance and Peer Review: This article was commissioned by the editorial office, Annals of Translational Medicine for the series "Liver News Column". The article has undergone external peer review.

Peer Review File: Available at http://dx.doi.org/10.21037/ atm-21-2136

Conflicts of Interest: All authors have completed the ICMJE uniform disclosure form (available at http://dx.doi. org/10.21037/atm-21-2136). The series "Liver News Column" was commissioned by the editorial office without any funding or sponsorship. NMS served as the unpaid Guest Editor of the series. The authors have no other conflicts of interest to declare.

Ethical Statement: The authors are accountable for all aspects of the work in ensuring that questions related to the accuracy or integrity of any part of the work are appropriately investigated and resolved.

Open Access Statement: This is an Open Access article distributed in accordance with the Creative Commons Attribution-NonCommercial-NoDerivs 4.0 International License (CC BY-NC-ND 4.0), which permits the noncommercial replication and distribution of the article with the strict proviso that no changes or edits are made and the original work is properly cited (including links to both the formal publication through the relevant DOI and the license). See: https://creativecommons.org/licenses/by-nc-nd/4.0/.

\section{References}

1. European Association for the Study of the Liver. EASL Clinical Practice Guidelines for the management of patients with decompensated cirrhosis. J Hepatol 2018;69:406-60.

2. Arroyo V. Review article: albumin in the treatment of liver diseases--new features of a classical treatment. Aliment Pharmacol Ther 2002;16 Suppl 5:1-5.

3. Garcia-Martinez R, Caraceni P, Bernardi M, et al. Albumin: pathophysiologic basis of its role in the treatment of cirrhosis and its complications. Hepatology 2013;58:1836-46.

4. Ashour AA, Atta MA, Sadek KW, et al. Albumin administration in patients with decompensated liver cirrhosis: a meta-analytic update. Eur J Gastroenterol Hepatol 2021;33:479-86.

5. Sandi BB, Leão GS, de Mattos AA, et al. Long-term albumin administration in patients with cirrhosis and ascites: A meta-analysis of randomized controlled trials. J Gastroenterol Hepatol 2021;36:609-17.

6. China L, Freemantle N, Forrest E, et al. A Randomized Trial of Albumin Infusions in Hospitalized Patients with Cirrhosis. N Engl J Med 2021;384:808-17.

7. Termsinsuk P, Auesomwang C. Factors that predict recurrent spontaneous bacterial peritonitis in cirrhotic patients. Int J Clin Pract 2020;74:e13457.

8. Sort P, Navasa M, Arroyo V, et al. Effect of intravenous albumin on renal impairment and mortality in patients 
with cirrhosis and spontaneous bacterial peritonitis. $\mathrm{N}$ Engl J Med 1999;341:403-9.

9. Bai Z, Guo X, Tacke F, et al. Association of serum albumin level with incidence and mortality of overt hepatic encephalopathy in cirrhosis during hospitalization. Therap Adv Gastroenterol 2019;12:1756284819881302.

10. Bai Z, Bernardi M, Yoshida EM, et al. Albumin infusion may decrease the incidence and severity of overt hepatic encephalopathy in liver cirrhosis. Aging (Albany NY) 2019;11:8502-25.

11. Sterns RH, Riggs JE, Schochet SS Jr. Osmotic demyelination syndrome following correction of hyponatremia. N Engl J Med 1986;314:1535-42.

12. Caraceni P, Riggio O, Angeli P, et al. Long-term albumin administration in decompensated cirrhosis (ANSWER): an open-label randomised trial. Lancet 2018;391:2417-29.

Cite this article as: Bai Z, Cheng G, Méndez-Sánchez N, Qi X. Human albumin infusion strategy in liver cirrhosis: liberal or restrictive? Ann Transl Med 2021;9(14):1114. doi: 10.21037/ atm-21-2136
13. Di Pascoli M, Fasolato S, Piano S, et al. Long-term administration of human albumin improves survival in patients with cirrhosis and refractory ascites. Liver Int 2019;39:98-105.

14. Solà E, Solé C, Simón-Talero M, et al. Midodrine and albumin for prevention of complications in patients with cirrhosis awaiting liver transplantation. A randomized placebo-controlled trial. J Hepatol 2018;69:1250-9.

15. Shasthry SM, Kumar M, Khumuckham JS, et al. Changes in cardiac output and incidence of volume overload in cirrhotics receiving $20 \%$ albumin infusion. Liver Int 2017;37:1167-76.

16. Villanueva C, Colomo A, Bosch A, et al. Transfusion strategies for acute upper gastrointestinal bleeding. N Engl J Med 2013;368:11-21. 